\title{
Pierre Batcheff, the surrealist star
}

Phil Powrie Newcastle University

with Eric Rebillard Association Française de Recherche sur l'Histoire du Cinéma

\begin{abstract}
Pierre Batcheff was one of the foremost jeunes premiers of 1920s cinema. Unlike his fellow stars, he despised the commercial films he made, and engaged with the surrealists and their sympathizers, leading to his role as the Man in Un Chien Andalou in 1929. In this article, we argue that Batcheff's performance style, which more often than not involved distancing himself from the action and from his female screen partners, and his star persona as the exotic other, contributed to make him what might seem like a contradiction in terms: a surrealist star. We show how the ideological preoccupations of the surrealists at the end of the 1920s, whether in relation to literature (Breton), painting (Dalí), or cinema (Artaud), intersected with those of Batcheff, making him an exemplary uncanny object, as defined by Hal Foster's work on surrealism.
\end{abstract}

\section{Keywords}

Pierre Batcheff

surrealism

masculinity

André Breton

Antonin Artaud

Salvador Dalí 
Pierre Batcheff is best known today as the Man of the avant-garde classic, Un Chien Andalou/An Andalusian Dog (1929), by Luis Buñuel and Salvador Dalí, made as a result of Batcheff meeting Buñuel during the production of La Sirène des tropiques/The Siren of the Tropics (1927), for which Buñuel was an assistant director. By 1929 Batcheff was one of France's top stars, while Buñuel and Dalí were unknown outside a small surrealist circle. As late as 1975, Batcheff was still considered to be the best French actor of the period 19251929 by Georges Sadoul, who was originally part of the surrealist group (Sadoul 1975: 106). Batcheff's biography is striking for his rapid rise to stardom, and the fact that he was, unlike many of his peers, an unwilling star. His first major role was at the age of sixteen in 1924. By the time of his death by suicide in 1932, he had made twenty-five films, two of them being made in alternate language versions. Nine of these premiered in the two-year period 19271928. His films were of varying quality, and he quite openly despised many of them. Amongst them, however, there are a number of films by major silent cinema directors: Jean Epstein (Le Double amour/Double Love, 1925), Marcel L'Herbier (Feu Mathias Pascal/The Late Mathias Pascal, 1925), Raymond Bernard (Le Joueur d'échecs/The Chess Player, 1927), Abel Gance (Napoléon, 1927), René Clair (Les Deux timides/Two Timid Souls, 1928), and Henri Fescourt (Monte-Cristo, 1929). Nonetheless, he considered the majority of the films he acted in to be no more than hack work, and longed to become a director. This was particularly the case after his involvement with Buñuel, and other members of the surrealist group such as Robert Desnos, this being followed by a very close association with the group forming around Jacques Prévert in the early 1930s, with whom he wrote screenplays. This article will argue that, unlike his fellow stars of the 1920s, Batcheff was what might be considered to be almost a contradiction in terms, a surrealist star, and this for more reasons than his participation in what has often been called the only truly surrealist film. 
Figure 1: 'Pierre Batcheff, who is one of the screen's best jeunes premiers' (Pour vous October 1929).

\section{The jeune premier}

Batcheff was one of a small group of young stars called jeunes premiers, young romantic male leads, and indeed one of the better-known ones. Pour vous ran a competition in 1928 , just after the premiere of Batcheff's next best-known film, Les Deux timides, to decide who the top six jeunes premiers were. Batcheff was the only clear French star in a list made up of American and British actors: Walter Byron, Alexandre D'Arcy, Reginald Denny, Douglas Fairbanks, along with Eric Barclay whose career began in the United Kingdom in the early 1920s and who made films in both France and Germany in the mid-1920s (Pour vous 1928: 12-13). The jeune premier was part of a well-established tradition in French iconography of the nineteenth century, the androgynous ephebe in history painting after the Revolution connoting 'effeminacy, passivity, debility, helplessness and impotence' (Solomon-Godeau 1997: 150). Batcheff also conformed to the image of the Romantic hero much loved by the surrealists. A description of him on the set of Monte-Cristo in 1928 plays on key Romantic figures, such as Don Juan, Alfred de Musset and Lord Byron, as well as a key figure for the surrealists from later in the century, child-poet Arthur Rimbaud:

The lips of a young Don Juan, short laughs, a capricious voice, that comes in fits and starts... Musset at eighteen. And the wilful but also faraway gaze that Byron must have had. Slim as a razor, nervous and quick, he makes you think of the bad boy of legends. His hair isn't ruffled yet, his clothes are not rags, he 
doesn't have those wide eyes like Rimbaud, but the Romantics would have seen him as a brother (Frank 1928: 8-9).

Figure 2: Claudine et le poussin (1924): Batcheff lies in Claudine's arms (Dolly Davis) (Collection Roche-Batcheff).

The image of the impotent youth reflected not just a reaction against the virility of the soldier damaged in the male-dominated and very public theatre of the Great War, but also a wish to return to the feminine, associated with domestic and maternal bliss, as Janine Bouissounouse argued in an article in Cinémonde in 1933, at a time when the jeune premier had changed to a more athletic and proletarian type. Her intentionally ironic sketch, with its almost blasphemous and no doubt unintentional references to the Pieta, could not better describe Batcheff's role in Claudine et le poussin (Claudine and the Youngster, Marcel Manchez) at the age of sixteen in 1924: 'After the war, no doubt to find relief from the soldiers ... women loved Cherub, a pale and fragile ephebe that you would have liked to cradle in your arms while singing a romance, cover with flowers and pamper' (in Cadars 1982: 21). Her argument does not just apply to film stars, but to some of the surrealist group (and by extension, one might argue, to many French intellectuals of the 1920s). Denise Tual, Batcheff's wife, explains in an interview in 1985 that Batcheff without being homosexual was a "feminine man", something specific to the times ... Take Aragon, Dalí, Éluard: all of them were extremely feminine men who had the habit of looking at themselves in the mirror. Their attitudes, their behaviour, without being specifically homosexual, was attractive to some women' (Gilles 2000: 191). 
A persistent trope for Batcheff's characters is the passive suffering male, drooping Pieta-like in a woman's arms. And yet, Batcheff's contact with his female partners on screen - amongst them Josephine Baker, Dolly Davis, Claude France, Edith Jehanne, Nathalie Lissenko, Gina Manès, Edna Purviance and Suzy Vernon - is curiously distant; a persistent trope in his star performance is the faraway or downcast look, even as he sits (or, frequently, lies incapacitated) close to the woman he loves, reminiscent of yet another Romantic icon, Percy Bysshe Shelley as we see him washed up dead on a beach in Edward Onslow Ford's Shelley Memorial.

Figure 3: La Sirène des tropiques (1927): Papitou (Josephine Baker) cares for the wounded André (Courtesy of the Bibliothèque du Film, Paris).

Figure 4: L'Île d'amour (1928): Xénia (Claude France) cares for the wounded Bicchi (Collection Roche-Batcheff).

Richard Dyer has shown how the distant or downcast look of the male pin-up functions as a disavowal of objectification. The faraway look is almost literally an escape, a spatial displacement from the passivity and commodified objectification of the spectator's gaze; the male pin-up's look off (what we are calling the distant look) 'suggests an interest in something else that the viewer cannot see - it certainly doesn't suggest any interest in the viewer' (Dyer 1992: 104). Dyer also points out that there are pin-ups who stare straight at the camera, and that their gaze to some extent reasserts masculinity by its 'penetrating' nature (1992: 109). Batcheff's gaze is hardly ever straight to camera, however. His gaze is not only 
looking away or off; it is literally vacant. He is there without being there; or, rather he is there, somewhere else, rather than being here; Batcheff is an absent presence.

Figure 5: L'Ile d'amour (1928): Batcheff as pin-up with a characteristic distant look (Collection Roche-Batcheff).

The distant look is also a disavowal of the femininity incorporated within that objectification; as Abigail Solomon-Godeau says of the nineteenth century pin-up, the ephebe, he combines 'the edifying and culturally sanctioned universe of male vertu and beauty, but leavened with a femininity contained, interiorized, and incorporated' (1997: 175). Femininity is inscribed within the pin-up as the giving-up of the body we see, while the distant look vacates the passive shell of the body; what is 'pinned-up' is a feminine-connoted residue, an abandonment. Masculinity as exemplified by Batcheff cannot be pinned up or pinned down; it is never there where you look because it has always already drifted somewhere else, evacuated. As Dyer has pointed out in relation to what he calls the Sad Young Man in popular culture: 'The sad young man is not yet a real man. He is soft; he has not yet achieved assertive masculine hardness. The sad young man is a martyr figure [and] embodies a mode of sexuality we might now label masochistic' (Dyer 1993: 42). He relates this historically both to the Romantic poets (whom we have seen are a constituent part of the French ephebe), as well as to Christian tradition of (male) martyrdom, particularly that of Saint Sebastian. Batcheff's characters frequently lie prone and suffering, drooping, passive objects in pain, 'looking off' in more ways than one.

Batcheff was not just 'vacant', he was also very much 'other'. He was originally an immigrant from a Russian family. There are frequent references in the popular press to his Russian origins, and it is more than likely that his films for the Russians of Montreuil, Films 
Albatros, would have intensified this association. There were likely to be 'oriental' touches as well, given that in the popular imagination the Russians were considered in the same bracket as the Chinese and Indochinese, a feature reinforced by Batcheff's birthplace in Manchuria, frequently commented on in star portraits. A sketch of French attitudes to the Russians in the 1920s brings out a feature that we shall find in Batcheff, that of the savage other: 'They were both ascetics and hedonists, fatalists and enterprising, tender and violent; the eyes of these disconcerting beings, full of an exquisite sensitivity, could be shot through with flashes of Asiatic savagery' (Schor 1996: 114). The 'savagery' that Batcheff's ethnic origins might have connoted was tempered by sensitivity, the words 'charming' and 'sensitive' being frequently used to describe him in star portraits. That said, given that the Polish immigrant community was one of the largest in France during the 1920s, as well as being one of the better organized (Schor 1996: 96-97), it is also likely that Batcheff would have been a vehicle for the working out of fantasies and fears relating to the frontiers of 'North Europeanness'. This would have been all the more the case given, first, nervousness in relation to possible 'Bolshevik' leanings of the Russian immigrants, and, second and more generally, the financial crisis of 1926 and the xenophobic discourses it generated (Schor 1996: 65).

Batcheff's Russianness, combined with 'Chinese' exoticism, linked him firmly with Rudolph Valentino, not least when Batcheff accepted Ingram's Berber role in Baroud (Rex Ingram, 1932) at the turn of the 1930s. Batcheff's role as Si Hamed was a clear reference to Valentino's The Sheik (1921) and The Son of the Sheik (1926), and Ramon Novarro's The Arab (1924). In this optic, Batcheff was not at all, or at any rate no longer, like the pale and fragile nineteenth century European melancholic; he was much more like the New World jeune premier so attractive to audiences on both sides of the Atlantic. 
Figure 6: Baroud (1932): Ahmed (Batcheff) draws his knife and prepares to kill André (Rex Ingram) (Photo R. Tomatis, Collection Roche-Batcheff).

\section{Surrealism, simulacra, and haunting}

Batcheff's 'vacancy' and otherness are signs of critical distance combined with rejection of the insipid jeune premier roles he hated. It is in our view clearly linked to a shift in surrealist thinking in 1928-1929, evident in the work of André Breton, as well as in the work of Dalí, in the form of paranoia-criticism, and also linked to Antonin Artaud's attempt to reconceive cinema language in the mid- to late-1920s.

In the second manifesto of surrealism, which appeared in the same number of $L a$ Revolution surréaliste as the filmscript of Un chien andalou, Breton lamented the fact that automatic writing, seen in the first manifesto of 1924 as one of the main vehicles for achieving the surreal, had in a few short years led to clichés. The reason for this, he suggested, was that those who practised automatic writing had not maintained a sufficient critical distance; aspiring surrealist writers 'were generally content to let their pens run rampant over the paper without making the least effort to observe what was going on inside themselves, this disassociation being nonetheless easier to grasp and more interesting to consider than that of reflected writing' (Breton 1972: 158). Batcheff's 'vacancy' can be seen as a broader ontological imperative, as a means of detachment in the sense used by Breton. Breton distanced himself from the persona adopted as a writer, with a view to bypassing the rational mind, so as to ensure the authenticity of the verbal flux. Batcheff, in a parallel move, distanced himself from the clichéd commercial roles he performed - both in his comments about them, and in the vacant look we have identified as a marker of disconnection from the performance itself - so as to ensure something more authentic, as he himself kept on saying in his star interviews, something closer to (his conception of) the real. 
Dalí was an important figure for the surrealists in the period 1929-1934, and his paranoiac-critical method, which Breton suggested could be applied to all the arts including cinema, adds another layer to the issue of distance and disassociation. The paranoiac-critical method, best illustrated in paintings by Dalí such as Métamorphose de Narcisse (1937), consists in replacing one image by its transformed or anamorphic double; but in principle, doubling is infinite. An example of the process in Un Chien Andalou is the sequence of dissolves (ants emerging from the hole in the hand, a woman's armpit, a sea urchin, the head of the androgyne). The images thus created are called simulacra by Dalí, and his view of their relationship to 'reality' is close to Baudrillard's simulacra, a key notion of postmodernism: not copies of the real, but the real itself, a dizzying circulation of always-already transformed images (Baudrillard 1981). We would like to argue that the jeune premier role is a simulacral image, all the more so in that there is no original image, only a constant circulation of variants of already existing images, performed by others as well as Batcheff. This is well exemplified by the illustration to one of Batcheff's star portraits, where we see a number of his roles pictorialized, neatly disposed in a circle, suggesting the circularity of simulacra.

Figure 7: 'Leurs visages' (Mon ciné, December 1928).

Artaud's trajectory was very similar to Batcheff's, although there is no evidence that they knew each other. He worked with Charles Dullin in L'Atelier (earlier than Batcheff), and with Georges Pitoëff (later than Batcheff); he took opiates like Batcheff; they both knew Dr Toulouse, the pioneering psychiatrist and Artaud's doctor; he used the cinema to support himself while lamenting its commercialism, like Batcheff; he wrote filmscripts, and like Batcheff, had one of his filmscripts, La Coquille et le clergyman/The Seashell and the 
Clergyman (1928), made into a film by someone else (Batcheff's was Amour ... Amour ..., cowritten with Jacques Prévert, and directed after his death by Robert Bibal, 1932). Artaud also acted in a number of films, most famously as Marat in Gance's Napoléon (1927), as had Batcheff in the role of General Hoche, but also in La Passion de Jeanne d'Arc/The Passion of Joan of Arc (Carl Theodor Dreyer, 1928), and in films by directors with whom Batcheff had also worked: L'Argent/Money (Marcel L’Herbier, 1929), and Tarakanova (Raymond Bernard, 1929).

In the course of 1927-1928 Artaud wrote a number of pieces concerning La Coquille et le clergyman. For Artaud, there are three sorts of cinema (Artaud 1961: 21-22). The first is narrative cinema based on rudimentary psychology, a translation of literary procedures to the screen. The second is pure cinema, which, in common with other surrealists, he dislikes for its formalist lack of emotion. The third type, he claims, is announced by La Coquille et le clergyman. Artaud does not abandon psychology, associated with narrative cinema, but claims that the new cinema will show human behaviour in its 'barbarity' (1961: 23), privileging desire over convention. The comments he makes concerning the circulation and disruptive nature of desire are close to Dalí's paranoiac-critical paradigm where an image is anamorphized into a succession of simulacra impelled by desire: 'The woman displays her animal desire, she has the shape of her desire, the ghostly sparkle of her instincts that force her to be the same but ever different in her repeated metamorphoses' (1961: 76).

A second, and rather more difficult notion to understand is Artaud's attempt to create a new language where images are disconnected from rational structures, 'images which emerge exclusively from themselves, and do not draw their meaning from the situation in which they develop but from a sort of powerful inner necessity' (1961: 23). The aim is to do for cinema what Breton had defined as the goal of surrealism in the first manifesto: to find 'the pure work of thought' (1961: 78). Indeed, Artaud suggests that images are redundant in 
this endeavour; cinema can express thoughts not through images, but 'with the matter that they are made of, without anything coming in-between, without representations' (1961: 8081). It is clear, however, that 'pure thought', however abstract and difficult to grasp it may be, in these circumstances can only be achieved by the kind of doubling and critical distancing that we have already seen in both Breton and Dalí. Artaud writes that spectators will only really understand his film if they are prepared to 'look deep into themselves' (1961: 82); 'an attentive examination of the inner self' (1972: 67). His scenario Les Dix-huit secondes (see Artaud 1961/1972) where 'one futile identification follows another, as the actor's centerless self goes from double to double' (Williams 1981: 29) shows how Artaud was grappling with individual identity as the principal problem in the accession to 'pure thought'. As Williams points out, and this reflects our view of Batcheff's work more generally, 'the actor has finally hit upon an identification with the actor in himself with an aspect of himself that is perpetually the reflection of the Other' (1981:29), in an uncanny doubling which we shall explore below.

We would like to suggest that Batcheff is a surrealist star; indeed, the only one, given that Artaud's relationship to the cinema was rather different. This might seem like the baldest of truisms. By common consent, there are very few 'surrealist' films, and the fact that Batcheff, one of the major commercial stars of the 1920s, acted in one of those very few films, indeed one of the even fewer that are labelled 'surrealist', by definition makes of him a surrealist star in ways that Gaston Modot, the hero of Buñuel and Dalí's next film, L'Âge d'or/The Golden Age (1930), was not, given that he was no more than a key second player of the French cinema throughout his career. Batcheff, on the other hand, mixed with the surrealists, and not just Buñuel and Dalí: Denise Tual reports that she and Batcheff were close friends of Robert Desnos (interview by Rebillard, November 1994). Moreover, as Tual points out, Batcheff wrote copiously, and in a surrealist mode, both in terms of the speed with 
which he wrote (an essential for surrealist automatic writing), making it difficult sometimes to read what he had written. But most of all, it is Batcheff's conscious distancing from his roles that point to a key surrealist interest. In a newspaper article he wrote in 1926, Batcheff contrasted cinema and real life, saying that life was 'an infinitely more attractive spectacle from the moment when you have the ability to turn yourself into the spectator of your own comedy’ (Batcheff 1926).

\section{The uncanny}

In more theoretical terms, Batcheff's critical distance from the roles he played parallels the distance from oneself promoted by Breton in the effort to discover what lies beneath the masks of identity, or as Breton puts it neatly in the first few lines of Nadja (1928): to discover whom I haunt. This notion of haunting is fundamental to surrealist aesthetics at the end of the 1920s, as it is to one of the more provocative studies of surrealism of the 1990s, Hal Foster's Compulsive Beauty, which argues strongly for a reading of surrealism as an engagement with the uncanny. Two broad points made by Foster are of relevance for our purposes. The first of these is the argument that surrealist objects can be viewed as the 'failed refinding of a lost object' (Foster 1993: xix). We would like to posit that Batcheff functions for the spectator as a 'lost object'. Then we want to consider Foster's productive contrast between two key surrealist figures, that of the automaton and the mannequin, and their link with Hans Bellmer's dolls. We will argue that they are the structuring devices for the performative simulacrum (what we call 'vacancy'), and its transformation into 'evacuation', a partly imposed, partly self-imposed disarticulation of the star-body.

Although clearly Batcheff is not quite like the object found apparently by chance, but rather an object actively sought, we would suggest that his function is similar. This is first because like the found object he is the locus of desire, revealing erotic latencies in the 
spectator. In this function he is no different we might say than any star. Where he begins to resemble the found object rather more is in his mysterious otherness, the sign of a beingother, of a being-elsewhere, cryptic and dislocated. Batcheff has always already vacated the location in which he acts; he is, as we suggested earlier, an absent presence, liminally there, but fundamentally elsewhere, figured by his deathly immobility and his deflected gaze, the looking away or off. In that sense he can never be graspable or recoverable.

Figure 8: Éducation de prince (1927): Batcheff exoticized and fetishized (Collection RocheBatcheff).

So what is in the 'there', the location which makes him 'not-here' and unavailable in his fullness? He is a fetish, tightly sheathed in figure-hugging black tails or tuxedos, or draped lasciviously in open-necked silk shirts, coyly revealing his neck and upper chest. The key figure for this in Un Chien Andalou, that repository of symptoms, is the wiping away of his mouth, as Simonne Mareuil, like the spectator, attempts to pin him down with her gaze. Batcheff's man, as earlier in the film, begins to become a woman, as her underarm hair - that has been read by more than one commentator as pubic hair - covers his mouth. The figure signals a double and disarticulated fetish: the penile body hidden beneath the costume is the 'missing' penis of the female, so that Batcheff, like any fetishized body, is rendered passive. This is then overlaid magically with a vagina; but this vagina has disappeared, leaving only what hides it, the hair, in what is a literal effacement and defacement of the male. Batcheff is doubly 'femaled', his maleness forever lost in what is, in the central section of the film, a poignant elegy to ruined masculinity. 
Batcheff is also absent because what we see is the past, a dislocation that is temporal as well as spatial. The temporal and the spatial come together in his otherness, his 'Russianness', connoting the alien culture and the fixed reference point of 1917, even if he did not mix with the White Russians. Batcheff is a displaced person. That displacement, we might wish to argue, is a complex mix. It is the result of 1917 , a social and historical alienation, a being-displaced; but it is also an enactment, or performance of displacement, a self-alienation (from himself and others). This emerges in comments on his voice: some say he has a Russian accent, others not. Evidence from Baroud, the only sound film we have been able to consult in its entirety, suggests not. It is of course entirely possible that spectators imagined a Russian accent where none existed, because this concurred with the otherness of his star persona. But it is not inconceivable that he played on his alienness, performing the border, acting out the cusp. Either way, Batcheff's in-betweenness is always on display, his identity convulsed like the Bretonian definition of beauty: exploding and fixed in the same moment, as we shall discuss below.

As spectators of stars we seek the renewed pleasure of past images, which is by definition lost. We attempt to recapture the identifications experienced as vicarious pleasure in the star body. In that sense, like desire itself, the attempt to capture the star body in its fullness can never succeed, because it is configured as a past experience. The present image of the star body on screen will always be 'read' as a fluid recombination of past images, haunting the present image uncannily precisely because they are from the past. The only way to refresh the image is to convulse it, which is what Un Chien Andalou tries to do. To be able to do so, it must use recognizable images, but reposition them within an unrecognizable context or narrative. The images of Batcheff in Un Chien Andalou, as Richard Abel rightly pointed out, are those we recognize from his previous films (Abel 1984: 483), returning uncannily to haunt the present image; but in addition, those images are distorted and further 
othered by their unrecognizable narrative context, where, crucially, time is made infinitely pliable, past and present too disarticulated for temporality to function as an anchor for the 'real'. The 'loosening' of time allows the uncanny to slip through in multiple doublings, sliding doors onto impossible landscapes (the first-floor room that suddenly opens onto a windswept beach).

Batcheff's star persona is essentially double, in the strongest sense of the word 'essential'; there are no spatial or temporal contingencies to constrain that uncanny doubling. This helps us to understand the doubling of his character in Un Chien Andalou, itself predicated on the doubling of the characters in his previous films. The two selves of $U n$ Chien Andalou are patterned on two of his main roles, that of the young lover, and that of the rebel-criminal. And that doubling underscores while excessively magnifying his star persona, which combines normality and a rejection of that normality.

The doubling generates the feeling of the uncanny, that which is both familiar and yet also strange. The double, or doppelgänger, is a key feature of the uncanny, which Freud relates to the fear of death: once a narcissistic projection of the ego in the form of spirits or the soul, and 'an assurance of immortality' to use Freud's words in his essay on 'The uncanny', the double becomes, as he puts it, 'the uncanny harbinger of death' (Freud 1955: 235). He also relates it to the capacity for self-observation, later defined by him as the superego. Audiences of Un Chien Andalou would have recognized the familiar, made strange by excess: the rolled-up ecstatic eyes and the gouged out eyes of the final shot are versions of the amorous gaze of the noble young lover; the frenetic pursuits are an excessive version of his normal although slightly stiff-armed gait, informed in Un Chien Andalou, as they had been to some extent in Les Deux timides, by the performances of comic actors such as Chaplin, Keaton and Sennett, for whom, particularly Keaton, Batcheff had very publicly professed his admiration. 
The uncanny for Freud was a resurgence of animistic mental activity, something which he himself would not necessarily have valorized, unlike the surrealists. Hence the paradox of Batcheff as exemplified in Un Chien Andalou: the film is a return to primitive modes of feeling, combining elements of reality and unreality, in an attempt to achieve surreality,. Batcheff's persona more generally articulates the same sensibility, with the same kind of consequences it had for Artaud: a feeling of living on the edge, of not inhabiting the body, of being someone else, of being a mere performance of masculinity. Batcheff, we are suggesting, is typical of a crisis in the male body which we see in other art-forms, but not typically in the other jeunes premiers of the period. This is no doubt because unlike Batcheff they did not mix with the avant-garde of the time, and therefore do not appear to have reflected on themselves in quite the way that Batcheff did. They were merely pin-ups, all surface; Batcheff is a pin-up wracked underneath by doubt, conflict, and inexpressibility; the familiarity of the jeune premier stereotype is shot through with the darker shadows and the anxiety of the alien doppelgänger.

Batcheff as pin-up is related to the uncanniness of the mannequin (as are the automaton and the doll). Foster links the mannequin to the Romantic ruin so as to explain how they tend to work together in surrealist practice: 'As the Bretonian pairing of the mannequin and the ruin implies, the mechanical-commodified and the outmoded are dialectically related: the mechanical-commodified produces the outmoded through displacement, and the outmoded in turn defines the mechanical-commodified as central' (1993: 126). Batcheff is both outmoded as Romantic jeune premier, and, by the same token, commodified as star and as replicable jeune premier. The 'vacancy' we have defined as his distinguishing feature renders him even more like a mannequin, we might argue, than his fellow jeunes premiers, with the possible exception of Jaque Catelain. Even Batcheff's turn to comedy in Les Deux timides and Un Chien Andalou, although arguably a break with the 
outmoded, is nonetheless, like any counter-cinema, dependent on what preceded it for us to understand it fully. Moreover, his Keatonesque performance with stiff walk and stiff arms, in both of those films, merely reinforces the mannequin-like effect of his persona.

As Bellmer said in a wonderfully apt statement, 'the body is like a sentence that invites us to rearrange it' (in Foster 1993: 103); and like Bellmer's dolls, we would suggest that Batcheff rearranged his persona through a variety of narratives, chosen by him, to perpetuate two terms that Foster usefully links: aura and anxiety. Like Bellmer's dolls, Batcheff consciously disarticulated his persona, 'evacuating' it, leaving behind the uncanny shell, the automaton-mannequin with the vacant gaze, the residue. That residue is both feminine and convulsive, desire exploding convention, to recall Artaud's views above. Foster explains how the surrealists projected aura and anxiety onto the figures we have been exploring so as to create the convulsive identity allowing access to the surreal. He also points out how the figures we have been referring to are generally feminine in surrealism, as if the other within, for the male poet, is an elemental femininity, with masculinity but an impotent mask, like make-up hastily applied at the surface. This is all the more the case when we remember that the figure determining the notion of beauty for Breton is feminine, and, like Artaud's view of pure thought, predicated on barbarous desire.

Figure 9: Feu Mathias Pascal (1925): the haunted look of Scipion the hysteric (Courtesy of the Bibliothèque du Film, Paris).

We have explored how doublings and splittings inform Batcheff's star persona: fatalist and enterprising; sensitive and savage; French and Russian; masculine and feminine. These crisscross and form the texture of Batcheff's performance. Batcheff, who frequented the 
surrealists more than he did his fellow actors, knew perfectly well what Breton meant by the definition of surrealism as the combination of two distant realities, and he put that definition into practice in his performance style. The doublings and splittings we have identified are not organized in binary configurations, as the preceding list undoubtedly suggests. They are a fluid network, best described in the same terms as one of Batcheff's first roles, in Feu Mathias Pascal: hysterical convulsions. Those convulsions underpin all of his roles, although they are much more evident in Un Chien Andalou.

Figure 10: Un Chien Andalou (1929): Batcheff hysterisized and othered (Courtesy of the Bibliothèque du Film, Paris)

Hysteria was a key surrealist interest in the mid-1920s. The last sentence of Nadja says 'Beauty will be CONVULSIVE or not at all' (Breton 1988: 753, his emphasis). The idea was taken up by Breton a few years later in an article entitled 'La beauté sera convulsive', where he wrote that 'Beauty will be erotic-veiled, exploding-fixed, magic-circumstantial' (Breton 1992: 687), the middle epithet, 'explosante-fixe' being illustrated by a Man Ray photograph of a faceless woman dancing with her skirt caught swirling around her (1992: 683). We would like to suggest that the explosante-fixe is emblematic of Batcheff's persona and trajectory. It encapsulates the femininity of the jeune premier, as well as the paralysis and passivity of cliché, the 'arrested motion of a body become an image' (Foster 1993: 27). And it is an exemplary illustration of what Elizabeth Bronfen calls the 'knotted subject', 'the snarled knot of memory traces, which as a wandering foreign body haunts the psyche' (Bronfen 1998: xiii), and which she considers to be less a symptom of repressed femininity than a mark of deep cultural shifts manifesting the vulnerability of the symbolic, of identity, and of course of the body itself. 
Breton's explosante-fixe also indicates the struggle by Batcheff to shake free of fixity, to explode the constraints in a convulsive frenzy of activity, to turn the inanimate mannequin, the lifeless automaton, into its ill-defined agonist, ultimately the writer-director that Batcheff longed to be. What Breton's position leads to is both an explosive tension and a disarticulation. That disarticulation is writ large onto Batcheff's body. His body is, to reprise Bellmer's statement, with all the ambiguities it might suggest of imprisonment and punishment, a rearranged sentence. Batcheff articulates a transitional masculinity, caught between a reactive post-(WWI)war idealism, expressed most clearly in the sanitized ephebe, and a newer pre-(WW2)war masculinity, that of the proletarian man of action, exemplified by Albert Préjean and Jean Gabin.

That this could only be achieved in a convulsive moment of comic violence tells us much about the period, but also much about the nature of masculinity more generally.

\section{References}

Abel, R. (1984), French Cinema: The First Wave, 1915-1929, Princeton: Princeton University Press.

Artaud, A. (1961), Euvres complètes, vol. 3, Paris: Gallimard.

Artaud, A. (1972), Collected Works, vol. 3 (trans. A. Hamilton), London: Calder and Boyars.

Batcheff, Pierre (1926), 'Article inédit de M. Pierre Batcheff', Argus de la Presse, Avignon, 14 August (Collection Roche-Batcheff).

Baudrillard, J. (1981), Simulacres et simulation, Paris: Galilée.

Breton, A. (1972), Manifestoes of Surrealism, (trans. R. Seaver and H. R. Lane), Ann Arbor, Mich.: University of Michigan Press. 
Breton, A. (1988), Euvres complètes, vol. 1, Paris: Gallimard.

Breton, A. (1992), Euvres complètes, vol. 2, Paris: Gallimard.

Bronfen, E. (1998), The Knotted Subject: Hysteria and its Discontents, Princeton: Princeton University Press.

Cadars, P. (1982), Les Séducteurs du Cinéma Français (1928-1958), Paris: Henri Veyrier.

Dyer, R. (1992), 'Don't look now: the instabilities of the male pin-up', in R. Dyer, Only Entertainment, London \& New York: Routledge.

Dyer, R. (1993), 'Seen to be believed: some problems in the representation of gay people as typical', in R. Dyer, The Matter of Images: Essays on Representation, London: Routledge.

Foster, H. (1993), Compulsive Beauty, Cambridge, Mass.: MIT Press.

Frank, N. (1928), 'Un Russe naturalisé Français par sa carrière: Pierre Batcheff', Pour vous, 6 (27 December), pp. 8-9.

Freud, S. (1955), 'The uncanny', in The Standard Edition of the Complete Psychological Works of Sigmund Freud, vol. 17, London: Hogarth Press.

Gilles, C. (2000), Le Cinéma des Années Trente par ceux qui l'ont Fait. Tome I. Les Débuts du Parlant: 1929-1934, Paris: L’Harmattan.

Pour vous (1928), 'Jeu de la veillée de Noël', Pour vous, 5 (20 December), pp. 12-13.

Sadoul, G. (1975), Histoire Générale du Cinéma. 5, L'Art Muet: 1919-1929. Premier Volume, L'Après-guerre en Europe, Paris: Denoël.

Schor, R. (1996), Histoire de l'Immigration en France, Paris: Armand Colin. 
Solomon-Godeau, A. (1997), Male Trouble: A Crisis in Representation, London: Thames and Hudson.

Williams, L. (1981), Figures of Desire: A Theory and Analysis of Surrealist Film, Urbana: University of Illinois Press.

\section{Contributor details}

Phil Powrie is Professor of French Cultural Studies at Newcastle University. He has published widely in French cinema studies, including French Cinema in the 1980s: Nostalgia and the Crisis of Masculinity (author, Oxford University Press, 1997), Contemporary French Cinema: Continuity and Difference (editor, Oxford University Press, 1999), Jean-Jacques Beineix (author, Manchester University Press, 2001), French Cinema: An Introduction (coauthored with Keith Reader, Arnold, 2002), The Cinema of France (editor, Wallflower Press, 2006), Carmen on Film: A Cultural History (co-author, Indiana University Press, 2007), The Films of Luc Besson: Master of Spectacle (co-editor with Susan Hayward, Manchester University Press, 2007). He has also co-edited an anthology on masculinities, entitled The Trouble with Men: Masculinities in European and Hollywood Cinema (Wallflower Press, 2004), and his work on the intersection between music and the cinema has led to two coedited volumes: Changing Tunes: The Use of Pre-existing Music in Film (Ashgate, 2006), and Composing for the Screen in Germany and the USSR: Cultural Politics and Propaganda (Indiana University Press, 2008). The present article is adapted from material in Pierre Batcheff and Stardom in the 1920s (Edinburgh University Press, forthcoming 2009). Contact: HASS Faculty Office, Daysh Building, Newcastle University, Newcastle upon Tyne NE1 7RU. Email: P.P.Powrie@ @ewcastle.ac.uk. 
Eric Rebillard is a member of the Association Française de recherche sur l'histoire du cinéma. He has published work on Pierre Batcheff with Phil Powrie in Buñuel, Siglo XXI (Institución Fernando el Católico/Prensas Universitarias de Zaragoza, 2004), and Marcel L'Herbier: l'Art du Cinéma (Association Française de Recherche sur l'Histoire du Cinéma, 2008). Contact: 10 rue du buisson Louis, 95470 Fosses, France. Email: erebilla@ yahoo.com. 